DURNAI, R ISIIT
(Rekayasa Sistem dan Teknologi Informasi)
Vol.3 No.3 (2019) $357-363 \quad$ ISSN Media Elektronik: $2580-0760$

\title{
Prediksi Indeks Harga Konsumen Menggunakan Metode Long Short Term Memory (LSTM) Berbasis Cloud Computing
}

\author{
Soffa Zahara ${ }^{1}$, Sugianto $^{2}$, M. Bahril Ilmiddafiq ${ }^{3}$ \\ ${ }^{12}$ Teknik Informatika, Fakultas Teknik, Universitas Islam Majapahit \\ ${ }^{3}$ Akutansi, Fakultas Ekonomi, Universitas Islam Majapahit \\ 11soffa.zahara@unim.ac.id, 25sugik2007@yahoo.com, ${ }^{3}$ ilmidaviq@gmail.com
}

\begin{abstract}
Long Short Term Memory (LSTM) is known as optimized Recurrent Neural Network (RNN) architectures that overcome RNN's lact about maintaining long period of memories. As part of machine learning networks, LSTM also notable as the right choice for time-series prediction. Currently, machine learning is a burning issue in economic world, abundant studies such predicting macroeconomic and microeconomics indicators are emerge. Inflation rate has been used for decision making for central banks also private sector. In Indonesia, CPI (Consumer Price Index) is one of best practice inflation indicators besides Wholesale Price Index and The Gross Domestic Product (GDP). Since CPI data could be used as a direction for next inflation move, we conducted CPI prediction model using LSTM method. The network model input consists of 28 variables of staple price in Surabaya and the output is CPI value, also the entire development of prediction model are done in Amazon Web Service (AWS) Cloud. In the interest of accuracy improvement, we used several optimization algorithm i.e. Stochastic Gradient Descent (sgd), Root Mean Square Propagation (RMSProp), Adaptive Gradient(AdaGrad), Adaptive moment (Adam), Adadelta, Nesterov Adam (Nadam) and Adamax. The results indicate that Nadam has 4,008 RMSE's value, less than other algorithm which indicate the most accurate optimization algorithm to predict CPI value.
\end{abstract}

Keywords: LSTM, Costumer Price Index, cloud computing

\begin{abstract}
Abstrak
Long Short Term Memory (LSTM) merupakan pengembangan salah satu algoritma deep learning yaitu Recurrent Neural Network (RNN) yang mengatasi salah satu kekurangan RNN yaitu kemampuan pengelolaan informasi dalam periode yang lama. LSTM banyak dipilih oleh untuk prediksi berbasis waktu atau time-series karena dikenal lebih unggul dan handal dalam melakukan prediksi dalam waktu lama dibanding algoritma lain. Topik inflasi banyak menjadi topik perbincangan karena menjadi salah satu faktor keberhasilan pengelolaan ekonomi dalam suatu negara juga menjadi faktor penentu kebijakan dalam bidang ekonomi. Di Indonesia, perhitungan inflasi dapat memakai nilai Indeks Harga Konsumen (IHK). Pembuatan model prediksi dalam penelitian ini menggunakan 28 jenis bahan makanan pokok sebagai input yang didapatkan dari Dinas Perdagangan dan Perindustrian Provinsi Jawa Timur, sedangkan output dari model prediksi yaitu nilai Indeks Harga Konsumen (IHK) didapatkan dari Badan Pusat Statistik Provinsi Jawa Timur. Keseluruhan proses pembangunan dan pengujian model prediksi dilakukan di lingkungan Cloud Computing dengan menggunakan Amazon Web Service (AWS) Cloud. Untuk meningkatkan akurasi dalam pembuatan model prediksi, penelitian ini menggunakan 7 algoritma optimasi yang berbeda yaitu Stochastic Gradient Descent (sgd), Root Mean Square Propagation (RMSProp), Adaptive Gradient (AdaGrad), Adaptive moment (Adam), Adadelta, Nesterov Adam (Nadam) dan Adamax. Hasil akhir menunjukkan algoritma terbaik untuk prediksi IHK yaitu Nesterov Adam (Nadam) memiliki nilai MRSE paling kecil dengan nilai 4,008.
\end{abstract}

Kata kunci: LSTM, Indeks Harga Konsumen, inflasi, cloud computing

(C) 2019 Jurnal RESTI

\section{Pendahuluan}

Penggunaan data mining untuk membangun model prediksi telah digunakan secara luas oleh para ahli untuk meningkatkan akurasi prediksi di berbagai sektor seperti ekonomi, kesehatan, olahraga, pendidikan, hingga pertanian dan peternakan. Prediksi di sektor ekonomi menjadi sangat penting ketika hasil prediksi yang akurat dapat membantu pemerintah dalam 
menentukan kebijakan selanjutnya. Salah satu indikator Beberapa penelitian tentang prediksi inflasi di ekonomi yang menjadi fokus pemerintah yaitu Indeks Indonesia telah dilakukan oleh beberapa ahli Harga Konsumen (IHK). IHK merupakan salah satu diantaranya, Krishnanti Dewi dkk [7] melakukan parameter di bidang ekonomi yang dikeluarkan oleh prediksi IHK menggunakan kelompok perumahan air, Badan Pusat Statistik (BPS) yang bertujuan listrik, gas, dan bahan bakar. Metode yang digunakan menginformasikan harga beli di tingkat konsumen [1]. yaitu SVR dan menggunakan MAPE (Mean Absolute Pergerakan harga beli di tingkat konsumen dari waktu Percentage Error) sebagai ukuran tingkat akurasi. ke waktu inilah yang menjadi dasar perhitungan IHK.

Di Indonesia, nilai IHK yang dikeluarkan tiap bulan dan tahun menjadi indikator inflasi yang paling sering digunakan selain Indeks Harga Perdagangan Besar (IHPB), Indeks Harga Produsen (IHP), Deflator Produk Domestik Bruto (PDB), dan Indeks Harga Aset [1]. IHK dipilih menjadi salah satu acuan inflasi sequensial dikarenakan frekuensi dan ketepatan waktu yang data IHK yang merupakan salah satu parameter inflasi dihasilkan. Selain inflasi yang berpengaruh dalam yang sewaktu-waktu dapat mempengaruhi kebijakan keputusan pemerintah dalam mengambil kebijakan sehingga penelitian ini bertujuan untuk melakukan ekonomi, IHK juga digunakan sebagai pertimbangan prediksi indeks IHK bulanan menggunakan algoritma berbagai aspek keuangan sosial seperti pensiun, LSTM. Data inputan model menggunakan data harga pengangguran dana alokasi dana pemerintah [2].

Di Indonesia perhitungan IHK sejak Januari 2014 meliputi 82 kota yang dikelompokkan menjadi 7 jenis komoditas yaitu 1. Bahan Makanan, 2. Makanan Jadi, Minuman, Rokok dan Tembakau, 3. Perumahan, Air, Listrik, Gas dan Bahan Bakar, 4. Sandang, 5. Kesehatan, 6. Pendidikan, rekreasi, dan olahraga, serta 7. transpor, komunikasi, dan jasa keuangan.

Deep learning dikenal sebagai algoritma pembelajaran terbaru yang mempunyai performansi handal dan mampu membangun model yang optimal dalam melakukan pemrosesan data [3]. Deep learning merupakan sub bagian dari machine learning yang menggunakan banyak layer sebagai media pemrosesan informasi non-linier. Salah satu jenis algoritma deep learning yaitu Long Short Term Memory (LSTM) yang merupakan pengembangan dari algoritma Recurrent Neural Network (RNN) dimana mengatasi masalah utama RNN yaitu tidak bisa mengolah informasi
sequensial dalam jangka panjang terutama pengolahan data yang bersifat time-series [4]

Gao dkk [5] dalam penelitiannya yang berjudul Applying Long Short Term Memory Neural Networks for Predicting Stock Closing Price, membangun permodelan untuk prediksi pasar saham menggunakan 4 metode yang berbeda yaitu Moving Average (MA), Exponential Moving Average (EMA), Support Vector Machine (SVM) dan LSTM. Dari hasil pengujiannya membuktikan bahwa LSTM mempunyai nilai keakuratan paling tinggi dibanding metode lainnya.

28 jenis bahan pokok makanan di Jawa Timur yang berasal dari Dinas Perindustrian dan Perdagangan Jawa Timur. Sedangkan untuk output prediksi menggunakan data IHK bulanan yang didapatkan dari BPS. Data hraga bahan makanan dan IHK diambil dari tahun 2014 sampai dengan 2018.

Untuk meningkatkan akurasi prediksi dalam penelitian menggunakan 8 jenis algoritma performansi yaitu Stochastic Gradient Descent (SGD), Root Mean Square Propagation (RMSProp), Adaptive Gradient (AdaGrad), Adaptive moment (Adam), Adadelta, Nesterov Adam (Nadam ) dan Adamax.

Pembangunan model prediksi dengan memakai lingkungan Cloud Computing menjadi populer dikarenakan semakin bertambahnya data publik yang dapat diakses oleh siapa saja untuk berbagai keperluan yang dapat diperoleh dengan berbagai teknik. Salah satu keunggulan yang dapat diperoleh dari penggunaan Cloud Computing yaitu pengguna tidak perlu memikirkan kompleksitas infrastruktur jika pembangunan sistem menjadi lebih kompleks dan besar sehingga memerlukan sumber daya komputasi yang lebih tinggi. Pembangunan model prediksi dalam penelitian ini menggunakan Amazon Web Service (AWS) EC2 virtual komputer untuk memudahkan dalam pengambilan raw data juga untuk meningkatkan waktu komputasi. EC2 (Elastic Compute Cloud) merupakan salah satu layanan AWS yang menyediakan komputasi virtual yang dapat dikonfigurasi sesuai kebutuhan pengguna [9].

Selain itu Jeenanunta dkk [6] juga telah membuktikañ

\section{2. Metode Penelitian}

dalam penelitiannya dimana membandingkan prediksi Pada Gambar 1 menjelaskan tahapan penelitian ini saham meggunakan metode LSTM dengan 3 jenis dibagi menjadi 6 tahap yaitu tahap pengambilan data prediksi saham komersial Thailand yaitu CPALL, SCB, kemudian dilakukan proses preprocessing yaitu proses dan KTB. LSTM berhasil mengungguli dengan nilai pembersihan dan tranformasi data, kemudian data performansi error kurang dari $2 \%$.

dialokasikan ke dalam data training dan data testing. Tahap selanjutnya yaitu pembangunan model prediksi

Jurnal RESTI (Rekayasa Sistem dan Teknologi Informasi) Vol . 3 No. 3 (2019) 357 - 363 
menggunakan LSTM di lingkungan Cloud Computing. Setelah model prediksi selesai lalu dilakukan evaluasi performansi akurasi dengan membandingkan algoritma performansi.

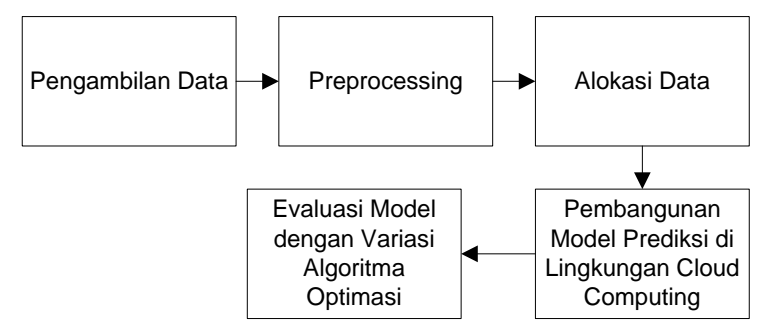

Gambar 1. Metode Penelitian

\subsection{Pengambilan Data}

Data yang digunakan dalam penelitian ini terbagi menjadi 2 jenis yaitu data input dan output. Data input penelitian berasal dari 33 jenis harga pokok bahan makanan di 38 kota Jawa Timur yang didapatkan secara online dari website Dinas Perdagangan dan Perindustrian Provinsi Jawa Timur yaitu http://siskaperbapo.com/ dengan periode pengambilan tahun 2014 sampai 2018. Kategori 28 jenis bahan makanan yang diambil yaitu :

1. Beras Bengawan

2. Mentik

3. Beras IR 64

4. Gula Pasir Dalam Negeri

5. Bimoli botol/kemasan 2 liter

6. Minyak Curah

7. Daging Sapi Murni

8. Daging Ayam Broiler

9. Daging Ayam Kampung

10. Telur Ayam Ras/Petelur

11. Telur Ayam Kampung

12. Susu Kental Manis Merk Bendera

13. Susu Kental Manis Merk Indomilk

14. Susu Bubuk Merk Bendera

15. Susu Bubuk Merk Indomilk

16. Jagung Pipilan Kering

17. Garam beryodium bata

18. Garam beryodium halus

19. Tepung Segitiga Biru

20. Kacang Kedelai Ekspor

21. Indomie Rasa Kari Ayam

22. Cabe Biasa

23. Cabe Rawit

24. Bawang Merah

25. Bawang Putih

26. Ikan Asin Teri

27. Kacang Hijau

28. Kacang Tanah

29. Ketela Pohon

30. Kol / Kubis

31. Kentang

32. Tomat

33. Wortel
34. Buncis

Dalam penelitian ini hanya memakai harga bahan makanan pokok dikarenakan data harga makanan mengalami fluktuasi yang cukup sering sehingga lebih cocok dijadikan data untuk prediksi. Sedangkan data output dari prediksi merupakan data indeks IHK yang dikeluarkan secara rutin tiap bulan oleh Badan Pusat Statistik (BPS) Jawa Timur periode pengambilan yang sama dari tahun 2014 sampai 2018.

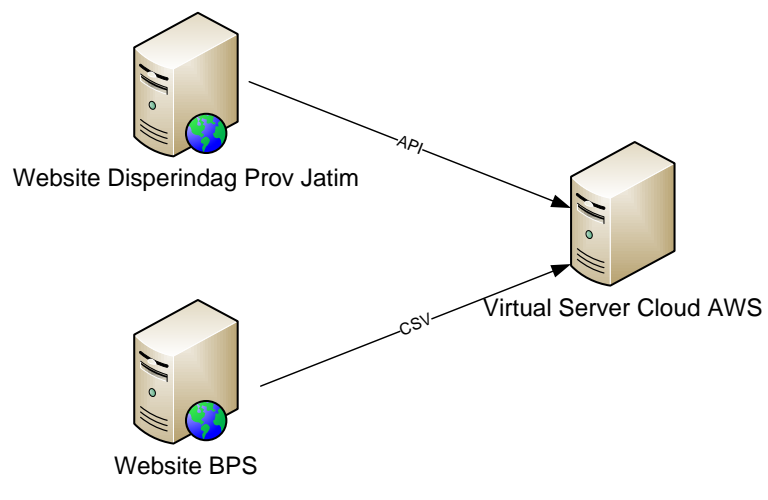

Gambar 2. Teknik Pengambilan Data

Gambar 2 mengilustrasikan teknik pengambilan data yang digunakan dalam pembangunan model prediksi. Data harga makanan pokok didapatkan dari website Disperindag melalui API (Application Programming Interface) yang telah disediakan. Sedangkan untuk data IHK yang diperoleh dari BPS diperoleh manual mengunduh file berformat CSV (comma delimited).

\subsection{Preprocessing}

Tahap preprocessing dalam penelitian ini dibagi menjadi 2 tahap yaitu tahap pemrosesan data yang hilang kemudian tahap selanjutnya yaitu scaling. Dalam proses pengambilan data bahan pokok terdapat beberapa data harga harian yang hilang, solusi dari masalah tersebut yaitu mengisi kekosongan data dengan rata-rata harga hari sebelumnya.

Setelah mengisi kekosongan data, tahap selanjutnya yaitu melakukan teknik scaling yaitu transformasi nilai data yang membuat nilai data menjadi lebih kecil skalanya tanpa mengubah informasi di dalamnya. Teknik ini dipakai untuk mengatasi masalah gap nilai yang cukup besar antara data bahan pokok dan data IHK. Scaling dilakukan dengan mengkonversi menjadi skala $(0,1)$ yaitu batas bawah 0 dan batas atas 1 .

\subsection{Alokasi Data}

Alokasi data membagi dataset menjadi 2 jenis yaitu training data atau data pembelajaran dan test data atau data uji coba. Dalam proses pembentukan model prediksi pembagian data training dan data testing yaitu $70: 30$. 
2.4. Pembangunan Predisi Menggunakan LSTM Lingkungan Cloud Computing

Pembangunan model prediksi IHK menggunakan bahasa pemrograman python dan beberapa library pendukung untuk machine learning yaitu scikit-learn, keras, numpy, matplotlib dan tensorflow.

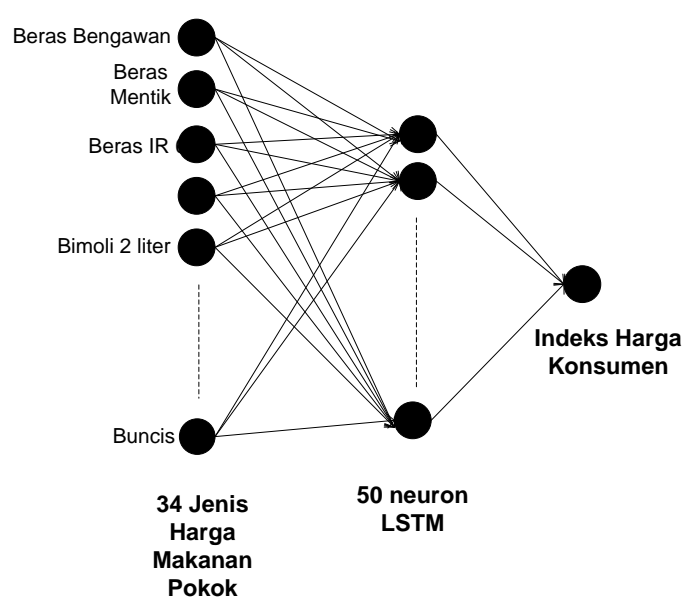

Gambar 3. Arsitektur Sistem Prediksi

Gambar 3 menggambarkan arsitektur LSTM yang digunakan terdiri dari sequensial input layer dimana sekuensial berarti tumpukan lapisan linear yang terdiri dari 34 variabel input. Data input tersebut kemudian diolah ke jaringan LSTM dengan 1 hidden layer yang terdiri dari 50 neuron. Data kemudian dialirkan ke output dense layer dengan 1 variabel output. Seluruh perpindahan layer menggunakan jaringan terkoneksi keseluruhan (fully-connected).

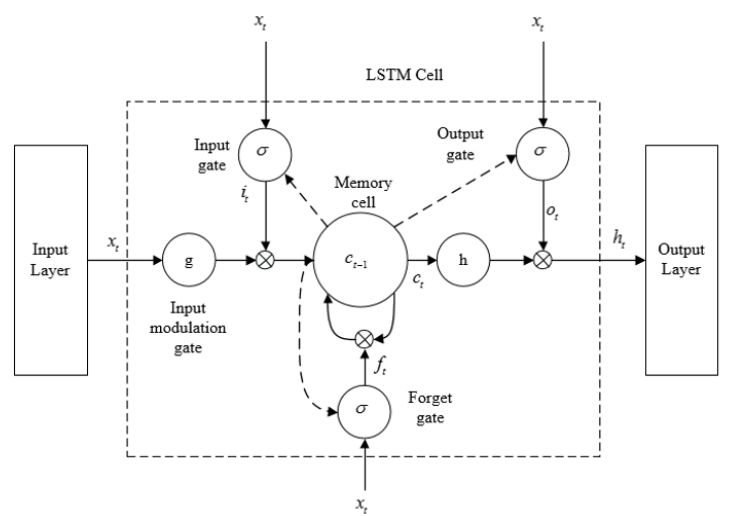

Gambar 4. Arsitektur LSTM [10]

Gambar 4 menggambarkan infrastruktur pemrosesan data dalam LSTM. LSTM merupakan salah satu pengembangan dari algoritma RNN (Recurrent Neural Network). Jika dalam arsitektur RNN biasa yang terdiri dari jaringan modul berulang yang berisi struktur fungsi layer tan sederhana. Jaringan LSTM digambarkan seperti beberapa modul berantai yang berulang dimana dalam setiap modul terdapat sub modul lagi yang berisi 3 fungsi gerbang sigmoid. Fungsi sigmoid merupakan fungsi yang mengatur jumlah informasi yang dilewatkan. 3 fungsi sigmoid utama yang berada dalam sub modul LSTM yaitu forget gate, input gate, dan output gate. Pada beberapa arsitektur LSTM yang dikembangkan seperti pada Gambar 4, selain 3 gerbang utama, biasanya terdapat 1 tambahan gate lagi yaitu input modulation gate.

Arsitektur metode LSTM secara garis besar dibagi menjadi 4 modul utama [10] yaitu input gate yang berfungsi membawa titik masuk data dari luar dan melakukan pemrosesan data yang masuk, input modulation gate, forget gate menentukan data mana yang akan dibuang dan menentukan jeda waktu optimal untuk input setelahnya, output gate memproses seluruh perhitungan masuk dan menghasilkan luaran atau output dalam LSTM cell.

Dalam proses perhitungan LSTM, input data yang berbentuk time-series dimisalkan sebagai $x=$ $\left(x_{1}, x_{2} \ldots, x_{n}\right)$ dan output $\mathrm{y}=\left(y_{1}, y_{2} \ldots, y_{n}\right)$ kemudian selanjutnya proses komputasi dilakukan dengan beberapa rumus sbb :

$$
\begin{aligned}
& h_{t}=H\left(W_{h x} x_{t}+W_{h h} h_{t-1}+b_{h}\right) \\
& p_{t}=W_{h y} y_{t-1}+b_{y}
\end{aligned}
$$

Dimana $\mathrm{W}$ adalah bobot dari matrik dan $\mathrm{b}$ adalah bias. Selanjutnya perhitungan hidden state dilakukan dengan rumus :

$$
\begin{aligned}
& i_{t}=\sigma\left(W_{i x} x_{t}+W_{h h} h_{t-1}+W_{i c} c_{t-1}+b_{i}\right) \\
& f_{t}=\sigma\left(W_{f x} x_{t}+W_{h h} h_{t-1}+W_{f c} c_{t-1}+b_{f}\right) \\
& c_{t}=f_{t} * c_{t-1}+i_{t} * g\left(W_{c x} x_{t}+W_{h h} h_{t-1}+\right. \\
& \left.W_{c c} c_{t-1}+b_{c}\right)(5) \\
& o_{t}=\sigma\left(W_{o x} x_{t}+W_{h h} h_{t-1}+W_{o c} c_{t-1}+b_{o}\right) \\
& h_{t}=o_{t} * h\left(c_{t}\right)
\end{aligned}
$$

Dimana $*$ merupakan hasil perkalian antara 2 matrik, sedangkan $\mathrm{g}$ dan $\mathrm{h}$ merupakan fungsi sigmoid dengan rentang nilai antara $[-2,2]$ dan $[-1,1] . \sigma$ merupakan fungsi sigmoid standar dengan rumus :

$$
\begin{aligned}
& \sigma(x)=\frac{1}{1+e^{x}} \\
& e=\sum_{t-1}^{n}\left(y_{t}-p_{t}\right)^{2}
\end{aligned}
$$

\subsection{Evaluasi Model dengan Algoritma Optimasi}

Setelah model prediksi berhasil dibangun maka akan dilakukan proses training sampai mencapai akurasi yang diinginkan. Proses ini menggunakan beberapa macam algoritma optimasi yaitu Stochastic Gradient Descent (sgd), Root Mean Square Propagation (RMSProp), Adaptive Gradient (AdaGrad), Adaptive moment (Adam), Adadelta, Nesterov Adam (Nadam) dan Adamax.

Stochastic Gradient Descent (sgd) merupakan salah satu varian dari optimasi gradient decent dimana selalu melakukan perubahan parameter di setiap data yang 
dilatihkan. Dalam melakukan update parameter, sgd Adamax, RMSProv, dan terakhir yaitu Adam tidak melakukan perulangan sehingga lebih cepat untuk mempunyai nilai RMSE terbesar.

dataset yang besar [11]. Sedangkan Adagrad yaitu algoritma optimasi berbasis gradient yang mengadaptasi variabel learning rate ke dalam parameter. Semakin banyak parameter yang di-update maka nilai learning rate-nya akan semakin kecil. Adagrad mewarisi sifat keandalan sgd, dan cocok untuk data skala besar.

Algoritma Adadelta merupakan pengembangan dari Adagrad yang menurunkan sifat agresif dari Adagrad dalam menurunkan nilai learning rate. Sedangkan kinerja dan tujuan algoritma RMSProp sangat mirip dengan Adadelta namun RMSProp mempu mengungguli Adagrad dalam menurunkan nilai learning rate.

Adaptive Moment Estimation (Adam) adalah metode optimasi yang menghitung tingkat pembelajaran secara adaptif untuk setiap parameter. Seperti halnya Adadelta dan RMSProp, Adam menyimpan rata-rata gradient proses sebelumnya secara eksponensial. Sedangakan Nadam (Nesterov-accelerated Adaptive Moment Estimation) merupakan kombinasi dari RMSProp dan Nesterov Accelerated Gradient (NAG).

RMSE (Root Mean Square Error) digunakan sebagai parameter akurasi dan efisiensi dari tiap algoritma optimasi. RMSE menghitung nilai kesalahan atau perbedaan antara data prediksi dan aktual.

$R M S E=\sqrt{\frac{1}{N} \sum_{i=1}^{N}(Y i-Y)^{2}}$

\section{Hasil dan Pembahasan}

Pembangunan model prediksi dilakukan di lingkungan cloud computing Amazon Web Service (AWS) tipe EC2 dengan detail spesifikasi pada Tabel 1.

Tabel 1.Tabel Spesifikasi Sistem

\begin{tabular}{lll}
\hline No & Jenis Kebutuhan & Spesifikasi \\
\hline 1 & Sistem Operasi & Ubuntu \\
& & Server \\
2 & Bahasa Pemrograman & Python 2.7.15 \\
3 & Machine Learning & Tensorflow 1.14 \\
& Backend & \\
4 & Machine Learning API & Keras 2.2.4 \\
5 & Library Pendukung & Mathplotlib 2.2.4 \\
& & Scikit-learn 0.20.3 \\
& & Numpy 1.2.2, \\
& & Pandas 0.24.2 \\
\hline
\end{tabular}

Setelah proses training dan testing dengan model prediksi LSTM yang telah dibuat, didapatkan hasil nilai RMSE pada Tabel 2.

Tabel 2 menginformasikan perbandingan nilai RMSE antara 7 agoritma optimasi setelah proses training dan testing. Dari tabel tersebut dapat diambil kesimpulan bahwa Nesterov Adam mempunyai nilai RMSE terkecil yaitu 4,088 diikuti dengan SGD, Adadelta, Adagrad,
Tabel 2.Tabel Hasil Nilai RMSE

\begin{tabular}{lcl}
\hline No & Jenis Metode & Nilai RMSE \\
\hline 1 & $\begin{array}{c}\text { Stochastic Gradient } \\
\text { Descent(sgd) } \\
\text { Root Mean Square } \\
2\end{array}$ & 4.219 \\
& 6.119 \\
3 & Propagation(RMSProp) & \\
& Adaptive & 5.435 \\
4 & Gradient(AdaGrad) & 6.926 \\
5 & Adaptive moment(Adam) & 5.207 \\
6 & Adadelta & 4.088 \\
7 & Nesterov Adam(Nadam) & 5.835 \\
\hline
\end{tabular}

Dari hasil pengujian akurasi terlihat bahwa Nadam atau Nesterov Adam membuktikan performasinya sebagai algoritma optimasi terbaru yang merupakan kombinasi antara RMSProp dan Adam mempunyai performansi terbaik diantara algoritma pendahulunya. Beberapa plot Gambar 5, 6, 7, 8, 9, 10 dan 11 mengilustrasikan perbandingan hasil prediksi dan data aktual di setiap algoritma optimasi.

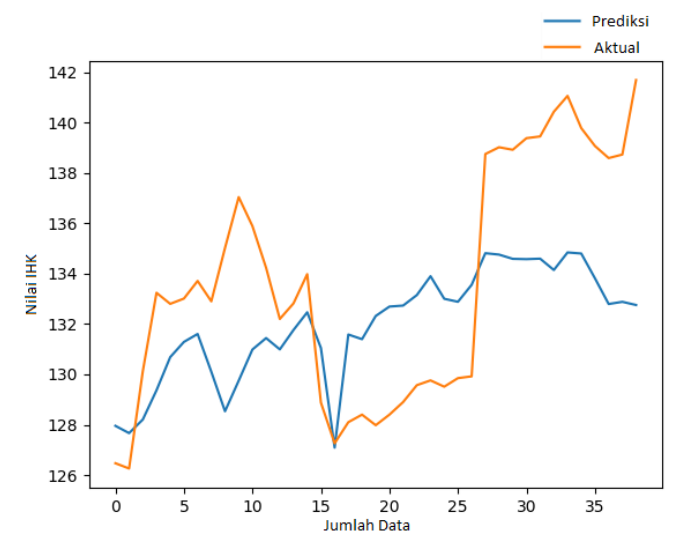

Gambar 5. Perbandingan Hasil Prediksi Menggunakan Stochatic Gradient Descent (SGD)

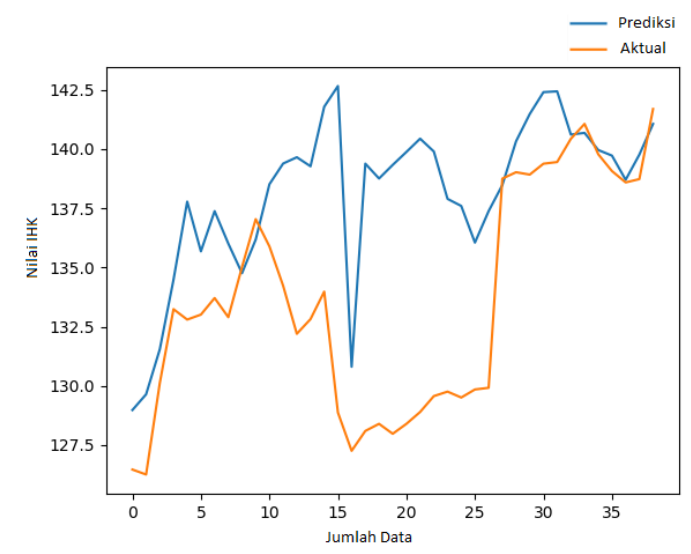

Gambar 6. Perbandingan Hasil Prediksi Menggunakan Root Mean Square Propagation (RMSProp) 


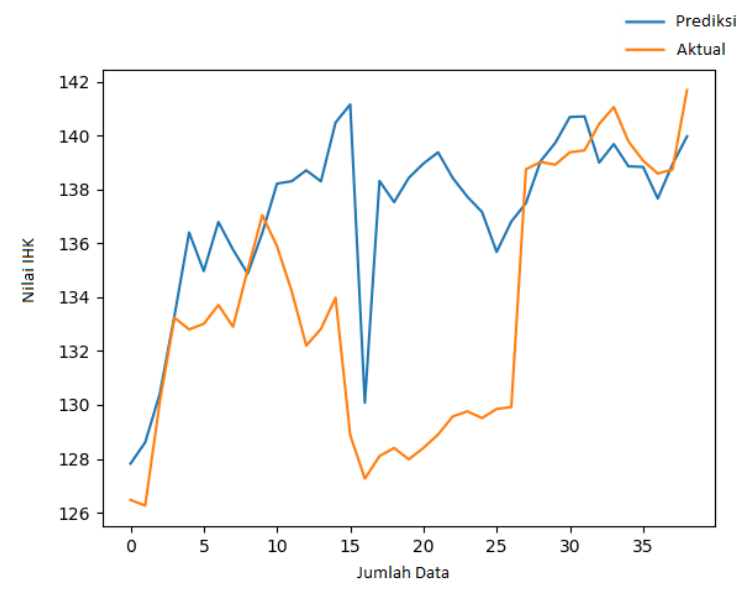

Gambar 7. Perbandingan Hasil Prediksi Menggunakan Adaptive Gradient (AdaGrad)

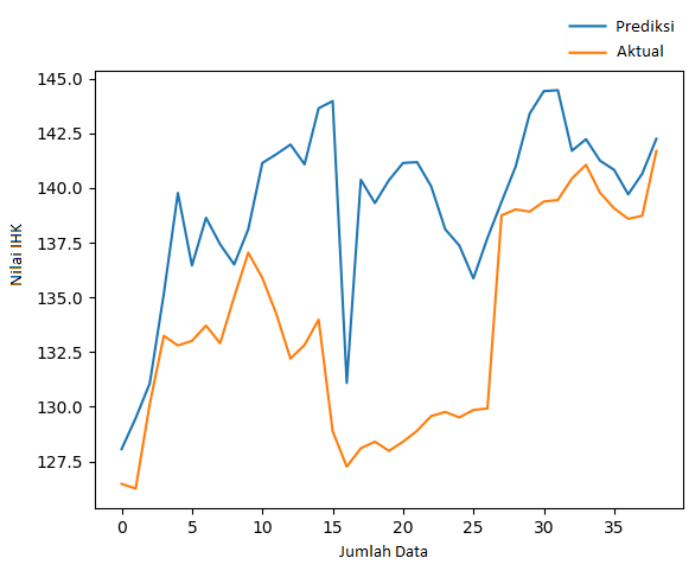

Gambar 8. Perbandingan Hasil Prediksi Menggunakan Adaptive moment (Adam)

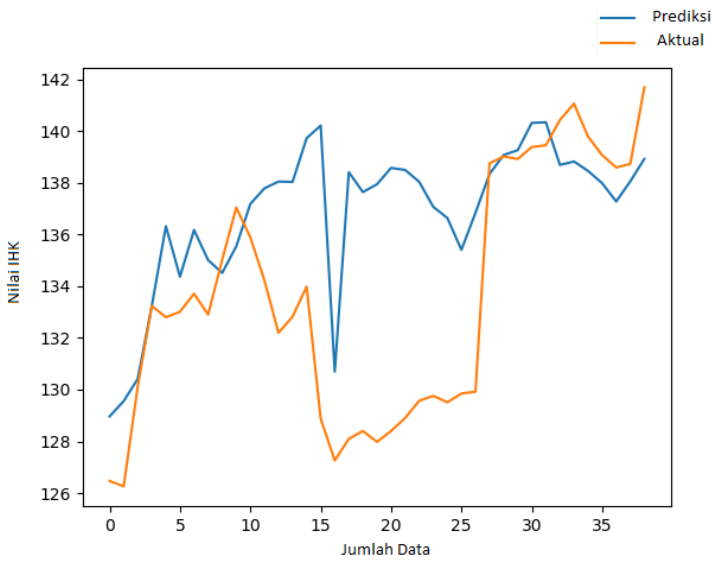

Gambar 9. Perbandingan Hasil Prediksi Menggunakan Adadelta

Tabel 3 menginformasikan perbandingan nilai IHK prediksi dan aktual menggunakan hasil algoritma optimasi terbaik berdasarkan hasil pengujian yaitu Nadam. IHK prediksi pada bulan Desember 2016 yaitu 133.98, mempunyai nilai prediksi yang paling mendekati nilai IHK aktual yaitu 133.98

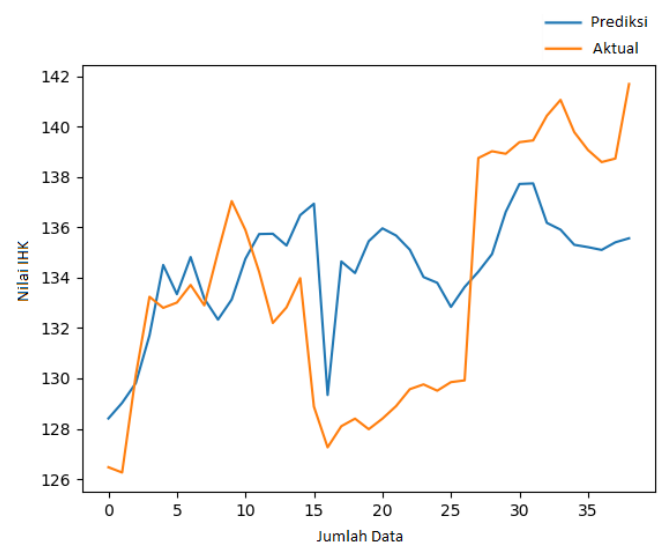

Gambar 10. Perbandingan Hasil Prediksi Menggunakan Nadam

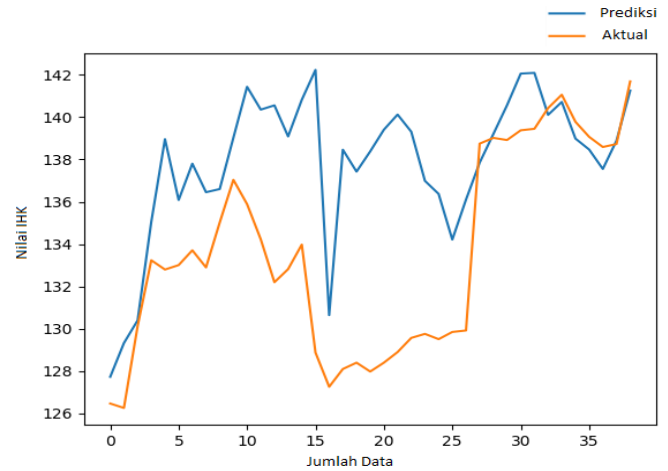

Gambar 11. Perbandingan Hasil Prediksi Menggunakan Adamax

.Tabel 3. Perbandingan IHK Aktual dan Prediksi Algoritma Nadam

\begin{tabular}{lrr}
\hline Periode & IHK Aktual & IHK Prediksi \\
\hline Mei 2016 & 132.9 & 128.0954 \\
Juni 2016 & 135.02 & 129.2686 \\
Juli 2016 & 137.04 & 130.3162 \\
Agustus 2016 & 135.89 & 132.2575 \\
September2016 & 134.23 & 135.2031 \\
Oktober 2016 & 132.2 & 133.6274 \\
November 2016 & 132.82 & 134.3239 \\
Desember 2016 & 133.98 & 133.1354 \\
Januari 2017 & 128.88 & 132.8289 \\
Februari 2017 & 127.26 & 133.9902 \\
Maret 2017 & 128.1 & 135.3659 \\
April 2017 & 128.4 & 135.6953 \\
Mei 2017 & 127.98 & 135.8108 \\
Juni 2017 & 128.4 & 135.5442 \\
Juli 2017 & 128.9 & 136.0939 \\
Agustus 2017 & 129.57 & 137.0477 \\
September 2017 & 129.76 & 129.4482 \\
Oktober 2017 & 129.51 & 135.3687 \\
November 2017 & 129.85 & 134.9568 \\
Desember 2017 & 129.92 & 136.0382 \\
Januari 2018 & 138.75 & 136.2948 \\
Februari 2018 & 139.02 & 136.2935 \\
Maret 2018 & 138.92 & 135.9997 \\
April 2018 & 139.38 & 135.9697 \\
Mei 2018 & 139.45 & 136.0438 \\
Juni 2018 & 140.43 & 134.831 \\
Juli 2018 & 141.06 & 135.6731 \\
Agustus 2018 & 139.78 & 136.6882 \\
September 2018 & 139.07 & 137.2478 \\
Oktober 2018 & 138.59 & 137.2249 \\
November 2018 & 138.73 & 137.3233 \\
Desember 2018 & 141.69 & 137.4724 \\
\hline
\end{tabular}


Dari hasil pengujian nilai RMSE tiap algoritma Daftar Rujukan

optimasi LSTM yang masih tergolong besar, terlihat bahwa metode LSTM belum bisa disebut metode yang maksimal dalam melakukan prediksi IHK. Terdapat banyak faktor yang mempengaruhi di antaranya yaitu nilai IHK yang fluktuatif terutama di bulan-bulan tertentu misal saat hari raya dan tahun baru. Selain itu perhitungan tahun dasar IHK yang berubah mengikuti tahun dasar Survey Biaya Hidup (SBH) juga sangat mempengaruhi.

\section{Kesimpulan}

Implementasi metode LSTM dalam prediksi yang bersifat time-series sangat tepat digunakan karena LSTM mampu mengingat dan menyimpan history data baik short term atau jangka pendek, maupun long term atau jangka panjang. Penelitian ini mengambil juga menggunakan variabel non linier yaitu harga pangan yang bersifat fluktuatif per hari dengan data prediksi IHK yang diterbitkan satu bulan sekali. Dari hasil training dan testing model prediksi yang dibangun dengan membandingkan 7 jenis algoritma optimasi, Nesterov Adam (Adam) mempunyai tingkat akurasi paling tinggi dibanding dengan algoritma lainnya dengan nilai RMSE terkecil yaitu 4.088. Meskipun hasil akurasi masih jauh dari harapan, beberapa faktor mungkin dapat dievaluasi untuk penelitian selanjutnya seperti variasi jumlah epoch, hidden layer, batch size, jumlah data training dan testing maupun penambahan variabel input dengan harapan mampu menambah nilai akurasi dari model prediksi.

\section{Acknowledgement}

Penelitian ini didukung dan didanai oleh Direktorat Riset dan Pengabdian Masyarakat, Direktorat Jenderal Penguatan Riset dan Pengembangan Kementerian Riset, Teknologi, dan Pendidikan Tinggi Republik Indonesia.
[1] D. Statistik, 2016, Metadata Indeks Harga Konsumen, [Online] (Updated Maret 2016) Tersedia di : https://www.bi.go.id/id/statistik/metadata/seki/Documents/12.I nflasi-Indeks Harga Konsumen (IHK-IND)2016.pdf. [Accesses 10 Juni 2019]

[2] ILO/IMF/OECD/UNECE/Eurostat/The World Bank. 2004. Consumer price index manual: Theory and Practice.1st ed. Geneva : Publications Bureau

[3] L. Deng, O. M. Way, D. Yu, and O. M. Way. 2014. Deep Learning: Methods and Applications. Foundations and Trends in Signal Processing. vol. 7. no. 2013. pp. 197-387.

[4] Hochreiter and J. Schmidhuber.1997. Long short-term memory. Neural Computation. vol. 9. no. 8. pp. 1735-1780.

[5] T. Gao, Y. Chai, and Y. Liu. 2018. Applying Long Short Term Momory Neural Networks for Predicting Stock Closing Price. 2017 8th IEEE International Conference on Software Engineering and Service Science (ICSESS). pp. 3-6. Beijing, China 24-26 Nov. 2017

[6] C. Jeenanunta, R. Chaysiri, and L. Thong. Stock Price Prediction With Long Short - Term Memory Recurrent Neural Network. 2018 Int. Conf. Embed. Syst. Intell. Technol. Int. Conf. Inf. Commun. Technol. Embed. Syst., pp. 1-7. Khon Kaen, Thailand 7-9 May 2018

[7] K. Dewi, P. P. Adikara, and S. Adinugroho. Prediksi Indeks Harga Konsumen ( IHK) Kelompok Perumahan, Air, Listrik, Gas Dan Bahan Bakar Menggunakan Metode Support Vector Regression. Jurnal Pengembangan Teknlogi Informasi dan Ilmu Komputer vol. 2, no. 10, pp. 3856-3862, 2018.

[8] I. A. Budiastuti, S. M. S. Nugroho, and M. Hariadi. Predicting daily consumer price index using support vector regression method. QiR 2017 - 2017 15th Int. Conf. Qual. Res. Int. Symp. Electr. Comput. Eng. Nusa Dua, Indonesia 24-27 July 2017

[9] A. W. Services. Amazon Elastic Compute Cloud User Guide for Linux Instances. [Online] (Updated 2019) Tersedia di : https://docs.aws.amazon.com/AWSEC2/latest/UserGuide/ec2ug.pdf [Accesses 20 Juni 2019

[10] R. Fu, Z. Zhang, and L. Li. Using LSTM and GRU Neural Network Methods for Traffic Flow Prediction. 2016 31st Youth Academic Annual Conference of Chinese Association of Automation (YAC). Wuhan, China 11-13 Nov. 2016

[11] S. Ruder. An overview of gradient descent optimization. [Online](Updated 19 Jan 2016) Tersedia di : https://arxiv.org/abs/1609.047477. [Accesses 19 Juni 2019] 